\title{
Refractory massive pleural effusion in systemic lupus erythematosus treated by pleurectomy
}

\author{
J S ELBORN, P CONN, AND S D ROBERTS \\ From the Royal Victoria Hospital, Belfast, Northern Ireland
}

SUMMARY A 34 year old man is described with systemic lupus erythematosus and recurrent massive pleural effusions. Systemic treatment with corticosteroids and azathioprine controlled all other manifestations of the disease apart from the pleural effusions. These were finally, successfully treated by pleurectomy.

Key words: respiratory disease, immune complexes, lymphocytes.

The lungs and pleura are frequently involved in systemic lupus erythematosus (SLE), the incidence varying in reports. ${ }^{1-3}$ Pleuritis or pleural effusion, or both, are the most common pleuropulmonary abnormalities seen, occurring in $50-75 \%$ of patients with involvement of the respiratory system. ${ }^{13}$ In more than half the cases effusions are bilateral. ${ }^{4}$

The characteristics of the pleural fluid in SLE are a protein level greater than $30 \mathrm{~g} / \mathrm{l}$, with normal glucose, lactate dehydrogenase greater than $200 \mathrm{IU}$, lymphocytosis (predominantly $\mathrm{T}$ cells), low total complement levels, and the presence of immune complexes. ${ }^{5}$ It has been shown that complement fractions and immunoglobulins are present also in the pleural tissues. These pleural findings, though characteristic of the pathology of SLE, do not contribute to the American Rheumatism Association (ARA) criteria for diagnosis. ${ }^{6}$

In most cases the pleural effusions of SLE do not require special treatment and resolve quickly. ${ }^{5}$ More persistent effusions respond rapidly to corticosteroids, combined if necessary with an immunosuppressive drug. Persistent effusions very refractory to treatment do occur in SLE, however. ${ }^{5}{ }^{8} \mathrm{We}$ report the case of a patient who, despite control of all other systemic manifestations of SLE, had a recurring massive pleural effusion persistent over

Accepted for publication 5 June 1986.

Correspondence to Dr J S Elborn. Royal Victoria Hospital. Belfast BT12 6BA. Northern Ireland. five months, with evidence of production of antibody in the pleura. This troublesome condition was successfully treated by pleurectomy.

\section{Case report}

A 34 year old man was transferred to the Royal Victoria Hospital, Belfast in November 1984 for treatment of a large recurrent left sided pleural effusion and active systemic lupus erythematosus (SLE). He had an eight month history of arthritis, recurrent mouth ulceration, diffuse alopecia, a photosensitive skin rash on face and arms, loss of energy, and weight loss of eight kilograms. He had developed dyspnoea on effort one month before admission, at which time $1000 \mathrm{ml}$ of pleural fluid had been aspirated at another hospital. During the eight months before his admission he had had two courses of prednisolone, $20 \mathrm{mg}$ daily, each lasting 14 days, which had helped his joint symptoms but not his dyspnoea.

By November 1984 he had a patchy erythematosus rash of his face and arms, diffuse mild alopecia, and a large left sided pleural effusion (Fig. 1). Physical examination was normal, including heart and blood pressure $(120 / 80 \mathrm{mmHg})$, and there was no evidence of cardiac failure. There was a normochromic, normocytic anaemia (haemoglobin $10 \cdot 7 \mathrm{~g} / \mathrm{dl})(107 \mathrm{~g} / \mathrm{l})$, white cell and platelet counts being normal. Westergren erythrocyte sedimentation rate was $80 \mathrm{~mm} / 1 \mathrm{st} \mathrm{h}$. Urea was slightly raised at 


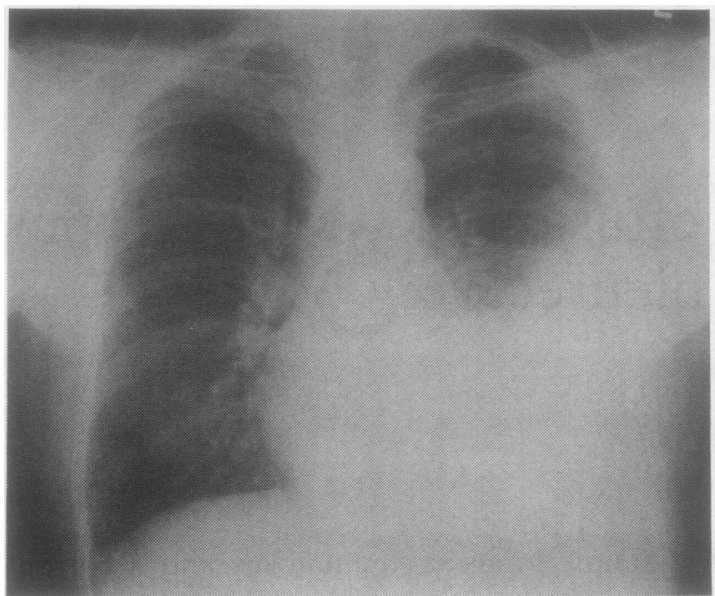

Fig. 1 Radiograph showing large left sided pleural effusion at presentation.

$12 \mathrm{mmol} / \mathrm{l}$ (normal 4-8), though creatinine clearance was normal $110 \mathrm{ml} / \mathrm{min}$ and serum creatinine $104 \mu \mathrm{mol} / \mathrm{l}$ (normal 40-110). Twenty four hour urinary excretion of protein was $2 \mathrm{~g}$. There was hypergammaglobulinaemia, IgG being $30 \mathrm{~g} / \mathrm{l}$ (normal 5-16), and antibody to nuclei was present at a titre of $1 / 80$ in IgG class. This reacted specifically with double stranded DNA (71 units/ml, normal range $0-25$ ) when assayed by the Farr technique. Antibodies to extractable nuclear antigens Ro and La were also present, identified by counterimmunoelectrophoresis. Serum complement levels were low: $\mathrm{C} 3=0.34 \mathrm{~g} / \mathrm{l}$ (normal $1-1.6$ ) and $\mathrm{C} 4=0.05 \mathrm{~g} / \mathrm{l}$ (normal $0 \cdot 12-0 \cdot 62$ ). Circulating immune complexes were demonstrated. The diagnosis of SLE was made on the basis of seven out of the 11 ARA 1982 revised criteria. ${ }^{6}$ A renal biopsy showed proliferative nephritis. His treatment was started with $40 \mathrm{mg}$ of prednisolone daily.

The pleural exudate aspirated was $950 \mathrm{ml}$, protein $49 \mathrm{~g} / \mathrm{l}$, lactate dehydrogenase $92 \mathrm{U} / \mathrm{l}$, glucose $7.2 \mathrm{mmol} / \mathrm{l}$. Pleural complement levels were low $(\mathrm{C} 3=0.22 \mathrm{~g} / \mathrm{l}, \mathrm{C} 4$ undetectable $)$, and immune complexes were demonstrated at $79 \mu \mathrm{g}$ of aggregated globulin. Cultures of pleural fluid and sputum were repeatedly negative for tubercle bacilli, fungi, and viruses. No abnormal cells were seen. Within four weeks the pleural effusion reaccumulated sufficiently to cause considerable dyspnoea on effort. Prednisolone was increased to $60 \mathrm{mg}$ daily and azathioprine started in a dosage of $150 \mathrm{mg}$ daily. Other clinical parameters of SLE activity now subsided, and ESR, immunoglobulins, and serum complement levels reverted to normal within
14 days. Proteinuria and haematuria resolved in 30 days. Despite further aspiration of $1900 \mathrm{ml}$ the left sided pleural effusion reaccumulated with marked dyspnoea. In December a further $2100 \mathrm{ml}$ of fluid was aspirated from the pleural cavity. In January 1985 a further $1000 \mathrm{ml}$ was aspirated, and this time $80 \mathrm{mg}$ of triamcinolone acetonide was instilled. The effusion recurred within five days. Two further aspirations were performed in February, removing $1000 \mathrm{ml}$ and $1100 \mathrm{ml}$. On each occasion reaccumulation and marked effort dyspnoea occurred within five days.

In March thoracoscopy was performed. Unusual whitish nodules were seen on the surface of the visceral pleura. A catheter was introduced and connected to an underwater seal. Over the following seven days this catheter drained $2000 \mathrm{ml}$ of fluid, and five days after its removal the effusion reaccumulated as before. A further drainage of $1200 \mathrm{ml}$ was performed two weeks later. A total volume of

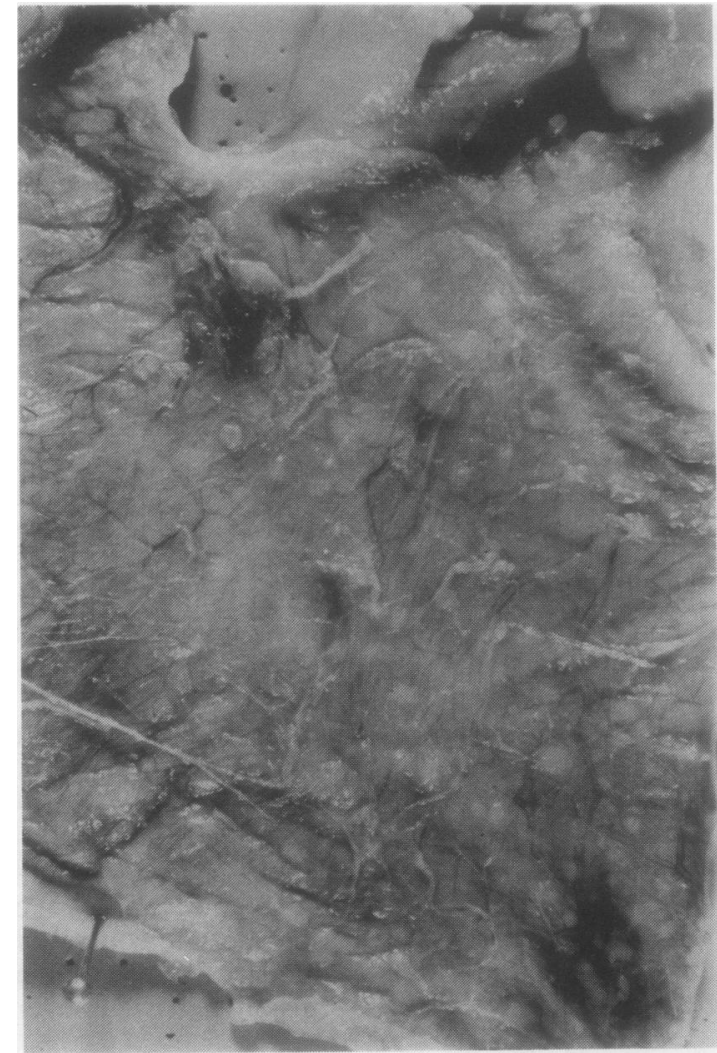

Fig. 2 Gross pathology specimen of resected parietal $\mathbb{D}$ pleura showing multiple nodules of histiocytes and plasma $\frac{O}{\mathbb{D}}$ cells. 


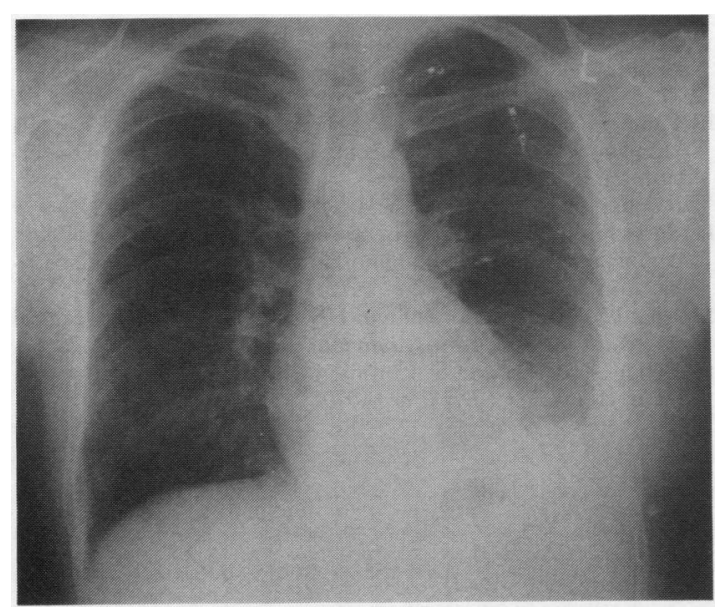

Fig. 3 Postoperative chest $x$ ray.

$12250 \mathrm{ml}$ pleural fluid had been removed over five months.

In April 1985 the patient underwent thoracotomy and left parietal pleurectomy. The pleura showed multiple white nodules measuring $1 \mathrm{~mm}$ in diameter on its surface (Fig. 2); these were composed of aggregates of histiocytes and plasma cells. Immunofluorescence showed these plasma cells to be secreting immunoglobulins, predominantly IgG. Complement components $\mathrm{Clq}$ and $\mathrm{C} 3$ were demonstrated around pleural blood vessels.

Twelve months' postoperatively there has been no recurrence of the effusion. Prednisolone dosage has been reduced to $9 \mathrm{mg}$ daily, and he continues on azathioprine $150 \mathrm{mg}$ daily. His chest $x$ ray shows pleural thickening at the left base (Fig. 3).

\section{Discussion}

Although pleural involvement is common in SLE, massive recurrent effusions are rare. ${ }^{67}$ Such effusions respond to corticosteroid and immunosuppressive treatment within weeks or months, rarely requiring thoracocentesis. In this patient unilateral pleural effusions recurred totalling more than 12 litres. Bacterial, tuberculous, fungal, and neoplastic conditions were excluded. Low complement levels and the presence of immune complexes in the pleural fluid suggested an immunopathological basis for the effusions. The effusions persisted over five months despite high doses of prednisolone and azathioprine, sufficient to control other manifestations of active SLE.

One mechanism suggested for the production of pleural effusions in SLE is the deposition of re- motely generated immune complexes in the pleural capillaries, which fix complement and release split complement fractions $\mathrm{C} 3 \mathrm{a}$ and $\mathrm{C} 5 \mathrm{a}$. It is these complement fragments that effect the increased vascular permeability, allowing fluid and proteins to escape into the pleural space. ${ }^{\circ}$ This suggestion gains support from the finding of low complement levels and immune complexes in SLE pleural effusions. ${ }^{9-11}$ If systemic activity of the disease generates the circulating immune complexes then the local capillary vascular tissue manifestations of SLE, which are presumed to include pleural effusions, ought to subside when systemic disease activity abates, but in this patient pleural disease continued despite otherwise complete clinical and laboratory control of systemic manifestations. Immune complexes and low complement levels persisted in the pleural fluid despite normal serum complement levels and the absence of immune complexes in the serum. This strongly suggests local production of immune complexes, probably in the pleura itself. Excessive and abnormal local aggregations of lymphocytes producing immunoglobulin were shown in pleural tissue in this case. We suggest that this is evidence supporting a locally generated immune reaction in this case.

We would speculate that the antibodies being produced might be cross reactive for anti-DNA and certain glycosaminoglycans present in pleural connective tissues, such as heparan and chondroitin sulphate, as recently suggested by Eilat for lupus nephritis. $^{12}$

If persistent pleural effusion in SLE is a purely local (pleural) phenomenon local intervention is logical. In one previous account of the treatment of massive recurrent pleural effusion successful treatment was achieved by talc poudrage. ${ }^{8}$ Bell and Lawrence have also reported two cases of chronic pleurisy in SLE, unresponsive to prednisolone and azathioprine, which were successfully treated by pleurectomy. ${ }^{13}$

This case report confirms that massive recurrent pleural effusions unresponsive to corticosteroids and immunosuppressive agents may occur in SLE. Pleurectomy proved successful in this case, and we would suggest that it is a logical and definitive treatment for such cases.

The authors thank Dr J Robb. and Mr J R P Gibbons for their help with this case. and Miss E O Prey and Mrs M Loughran for typing the manuscript.

\section{References}

I Gross M. Esterly J R. Earle R H. Pulmonary alterations in SLE. Am Rev Respir Dis 1972: 105: 572-7.

2 Hunningare $G \mathrm{~N}$. Fauci A $\mathrm{S}$. Pulmonary involvement in collagen vascular discases. Am Rev Respir Dis 1979; 119: 471-5()3. 
3 Haput H M. Moore W G. Huthins G M. The lung in SLE. Am J Med 1981; 71: 791-8.

4 Balgrin J G, Dubois E L, Jacobsen G. Chest roentgenographic changes in SLE. Radiology 1960; 74: 42-9.

5 Miqueres I, Tover A. Pleural involvement in systemic discases. In: Chretien J. Hirsch A, eds. Diseases of the pleura. USA: Marion Publishing, 1983: 188-97.

6 Tan E M, Cohen A S, Fries J F. et al. The revised criteria for the classification of SLE. Arthritis Rheum 1982; 25: 1271-7.

7 Rothfield W F. Cardiopulmonary manifestations. In: Schur P H ed. The clinical management of SLE. New York: Grune and Stratton, 1983: 113-22.

8 Kaine J C. Refractory massive pleural effusion in SLE treated with talc poudrage. Ann Rheum Dis 1985; 44: 61-4.
9 Schocket A C, Cain D. Kohler P F. Stigerwald J. Immune complex vasculitis as a cause of ascites and plcural effusions in SLE. J Rheumatol 1978; 5: 33-8.

10) Hunder G G. McDuffic F C. Huston K A. Elveback L R. Hepper N G. Pleural fluid complement, complement conversion and immunocomplexes in immunologic and nonimmunologic discases. J Lab Clin Med 1977; 90: 971-80.

11 Pertschuk L P. Moccia L F. Rosen Y. et al. Acute pulmonary complications in SLE. Immunofluorescence and light microscopic study. Am J Clin Pathol 1977: 68: 553-7.

12 Eilat D. Cross reactions of anti-DNA antibodies and the central dogma of lupus nephritis. Immunol Today 1985; 6: 123-7.

13 Bell R. Lawrence D S. Chronic pleurisy in SLE treated with pleurectomy. Br J Dis Chest 1979: 79: 1314-6. 